\title{
Pinuxylon woolardii sp. nov., a new petrified taxon of Pinaceae from the Miocene basalts of eastern Oregon
}

\author{
William D. Tidwell \\ Lee R. Parker \\ Vaughn K. Folkman
}

Follow this and additional works at: https://scholarsarchive.byu.edu/facpub

Part of the Geology Commons

\section{Original Publication Citation}

Pinuxylon woolardii sp. nov., a new petrified taxon of Pinaceae from the Miocene basalts of eastern Oregon. William D. Tidwell, Lee R. Parker, and Vaughn K. Folkman American Journal of Botany (November 1986), 73(11):1517-1524

\section{BYU ScholarsArchive Citation}

Tidwell, William D.; Parker, Lee R.; and Folkman, Vaughn K., "Pinuxylon woolardii sp. nov., a new petrified taxon of Pinaceae from the Miocene basalts of eastern Oregon" (1986). Faculty Publications. 1448. https://scholarsarchive.byu.edu/facpub/1448 


\title{
PINUXYLON WOOLARDII SP. NOV., A NEW PETRIFIED TAXON OF PINACEAE FROM THE MIOCENE BASALTS OF EASTERN OREGON ${ }^{1}$
}

\author{
William D. Tidwell, ${ }^{2}$ Lee R. Parker,${ }^{3}$ AND \\ VAUGHN K. FOLKMAN ${ }^{4}$

\begin{abstract}
${ }^{2}$ Department of Botany and Range Science, Brigham Young University, Provo, Utah 84602, ${ }^{3}$ Biological Science Department, California Polytechnic State University, San Luis Obispo, California 93407 , and ${ }^{4}$ Baker Senior High School, Baker, Oregon 97814
\end{abstract}

\begin{abstract}
A B S T R A C T
Specimens of the new species Pinuxylon woolardii have been collected from Miocene strata near Durkee, OR. These petrified specimens are unique in that, due to weathering, individual tracheids and ray cells can be separated for detailed SEM studies. This species is characterized by its high number of ray cells; numerous rays; large resin ducts which are commonly paired; primarily uniseriate pitting, two to five (usually three) small, oval or circular pinoid pits per crossfield; and smooth walls on its transverse (ray) tracheids. The latter character relates this species to taxa in the subgenus Haploxylon of Pinus. Pinuxylon woolardii is most similar to the fossil species Pinuxylon parryoides and the extant species Pinus aristata, $P$. cembroides, $P$. edulis, $P$. monophylla and $P$. balfouriana. These modern species live in dryer environments and at higher elevations than that suggested by the Miocene leaf floras which occur near the locality of $P$. woolardii.
\end{abstract}

THE LOCALITY where the pinaceous wood described in this paper was collected lies approximately four miles $(6.4 \mathrm{~km}) \mathrm{NW}$ of Durkee and 17 miles $(27.4 \mathrm{~km})$ SE of Baker, OR (Fig. 1). The locality is in the southeastern portion of the Blue Mountains geomorphic province which consists of a complex of mountain ranges, incised plateaus, and fertile valleys. Uplift and subsequent erosion of the Blue Mountain Region has resulted in irregular removal of $\mathrm{Ce}$ nozoic rock cover, exposing rocks of Triassic and Jurassic age in some areas (Brooks, McIntyre and Walker, 1976). The Middle and Upper Miocene strata where the fossil wood was collected are composed mainly of flow-on-flow basalts that rest unconformably on pre-Cenozoic strata. Beds of tuff and tuffaceous sedimentary rocks separate the flows in some areas and it is in these sediments that our fossil material was found. Platy and columnar jointing are prominent in some of the flows and some are vesicular, whereas others have scoriaceous flow tops. It has been suggested that along the Snake River, this basalt unit may be correlated with the Picture Gorge Basalt of the Columbia River Group (Waters, 1961; Brooks et al., 1976). Radioactive dating of this basalt would be required to validate this relationship (Gray and Kittleman, 1967). This basalt unit is unconformably overlain by Lower Pliocene vertebrate fossil-bearing lacustrine sedimentary rocks near Richmond, OR (Brooks et al., 1976).

${ }^{1}$ Received for publication 21 October 1985; revision accepted 21 March 1986.
A compression flora of Middle or Late Miocene age has been reported from a tuffaceous bed in the lower part of an equivalent basalt section near Sparta, OR (approx. 26 miles [41.8 $\mathrm{km}$ ] north of Durkee; SW $1 / 4$, Sec. 1 T7S, R43E of the Baker Quadrangle; Hoxie, 1965). The Sparta flora, named for this former mining town, is composed of 29 genera of leaf and fruit compressions and 26 genera of palynomorphs. Hoxie (1965) listed Pinus harneyana Chaney and Axelrod and Pinus wheeleri Cockerell from this flora.

In addition to the Sparta flora, there are seven major Miocene floras within a 100 mile ( 160 $\mathrm{km}$ ) radius of our locality. These include the Mascall, Blue Mountains, Stinking Water, Lower Idaho, Thorn Creek, Payette and Succor Creek floras. The Latah flora is approximately 225 miles $(362 \mathrm{~km})$ north of the Durkee site near Spokane, WA. Of the thirteen pinaceous species listed by Chaney (1959) from these floras, only three are assigned to Pinus. The remains of these fossil pine species consist of needles, twigs, seeds, and cones. Pinus harneyana Chaney and Axelrod is a fossil three needle pine whose relationship to modern pines is uncertain. Chaney and Axelrod (1959) state that the best match for this fossil species is $P$. ponderosa Lawson, while, such living species as $P$. taeda $\mathrm{L}$. and $P$. rigida Miller show a more distant relationship to $P$. harneyana. Pinus tipioniana Chaney and Axelrod, a fossil two needle pine, and Pinus wheeleri Cockerell, a fossil five needle pine, also occur in these floras. The cones of $P$. tiptoniana more closely resem- 


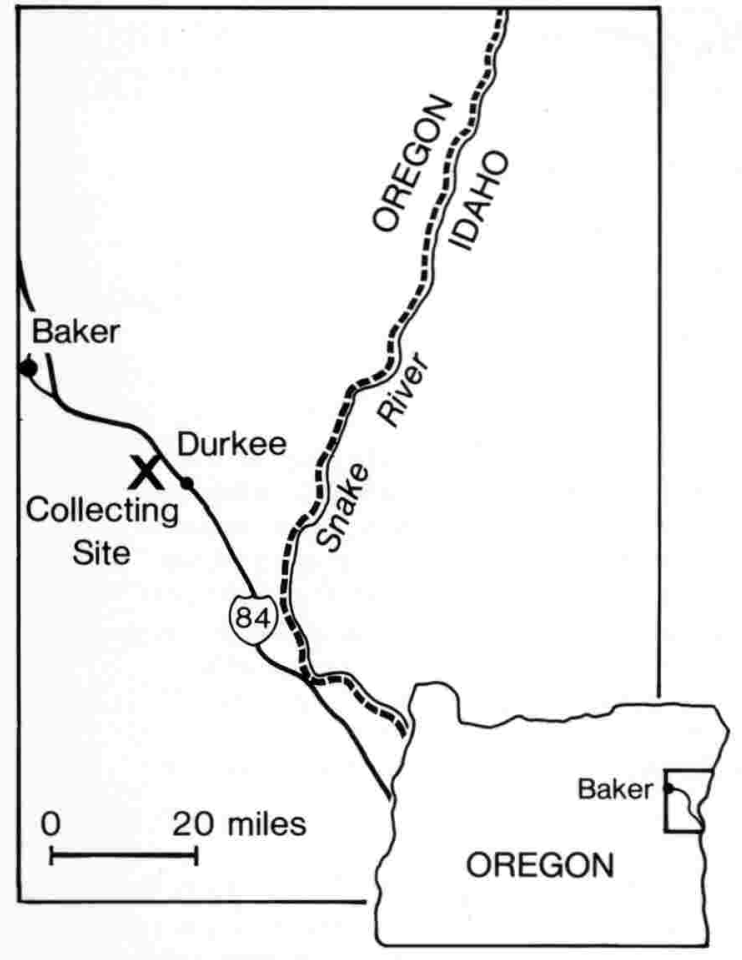

Fig. 1. Index map showing collecting locality of $\mathrm{Pi}$ nuxylon woolardii sp. nov.

ble those of the modern Aleppo pine ( $P$. halepensis Miller) of southern Europe; however, the needles of this fossil species are most similar to $P$. nigra of southern Europe or to $P$. echinata Miller. Pinus wheeleri shows a relationship to living $P$. monticola Douglas and $P$. strobus L. In order to determine if a relationship exists between the pinaceous wood under consideration and the known pine compression species, the fossil wood was compared to the wood of each of the nearest living relative suggested by the described compression species. No close correlation is apparent between them.

MATERIALS AND METHODS-The petrified wood which is the subject of this study was collected in 1982. The material is interesting in that, due to weathering, individual silicified tracheids and ray cells can be separated for detailed transmitted light microscopy and SEM studies. The odd, "fuzzy" appearance of the weathered ends of portions of this permineralized wood, attracted our initial interest in these specimens. Weathering appears to have removed the original cell wall, leaving the internal silica casts standing in relief (Fig. 12), and thus, producing the "fuzzy" texture. The silica casts were removed, stained with Bismark brown or malachite green and mounted for examination with the light microscope. Other casts of these cells were prepared for SEM studies. In addition, ground thin sections were prepared for study.

Family Pinaceae

Genus Pinuxylon Gothan, 1905

Pinuxylon woolardii sp. nov. (Fig. 2-12)

Transverse-Growth rings distinct, wide and relatively straight; transition from early to late wood gradual; early wood tracheids large, with large lumens, thin walls, rectangular to square in shape, occasionally circular; late wood cells small, tangentially oblong with thicker walls, flattened tangentially in late wood of each growth increment; vertical resin ducts large, 110 to $125 \mu \mathrm{m}$ in diam, relatively numerous, unevenly distributed, encountered close to growth ring limits of early wood, occasionally in late wood, often occurring in groups of two or three, 5-7 thin-walled, epithelial cells; rays separated by 2 to 7 (commonly 4 ) rows of tracheids; xylem parenchyma absent.

Tangential-Rays numerous, heterogeneous, uniseriate and fusiform, 8-21 cells high, mostly parenchyma, ray tracheids marginal; numerous fusiform rays with horizontal resin ducts, multiseriate in middle with uniseriate extensions at both ends, 5-6 thin-walled epithelial cells; ray cells oval, elliptical, or square to rectangular in shape; commonly $3-13 \mu \mathrm{m}$ in width, no intercellular spaces between ray parenchyma and longitudinal tracheids; small bordered pits occur on tangential walls of tracheids.

Radial-Radial pits bordered, separated, uniseriate, occasionally opposite biseriate or

Fig. 2-6. 2. A specimen showing the "fuzzy" aspect of the weathered tracheids. $\times 2$. 3. Closeup of tangential section illustrating a horizontal resin canal in a ray. Note portions of uniseriate rays on the left. $\times 400$. 4. Radial section of a portion of a ray showing the transverse (ray) tracheids; note the smooth walls of this tracheid. $\times 400$. 5. Radial section illustrating the uniseriate, sometimes biseriate, pitting of this species. $\times 400.6$. Scanning electron micrograph of the surface of a tracheid cast showing the casts of the pit cavities of two bordered pits. The wall has eroded away. $\times 3,700$. 


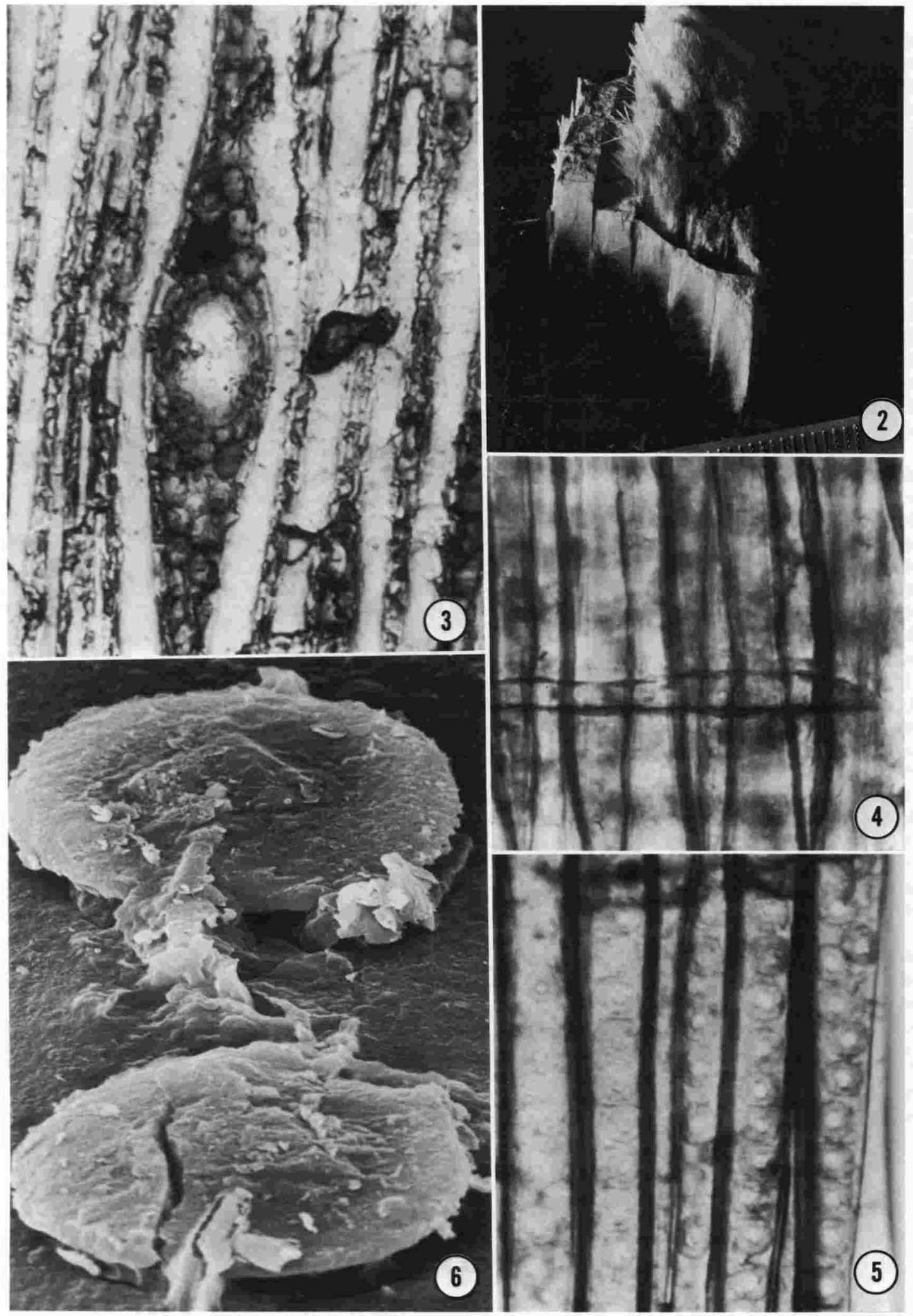



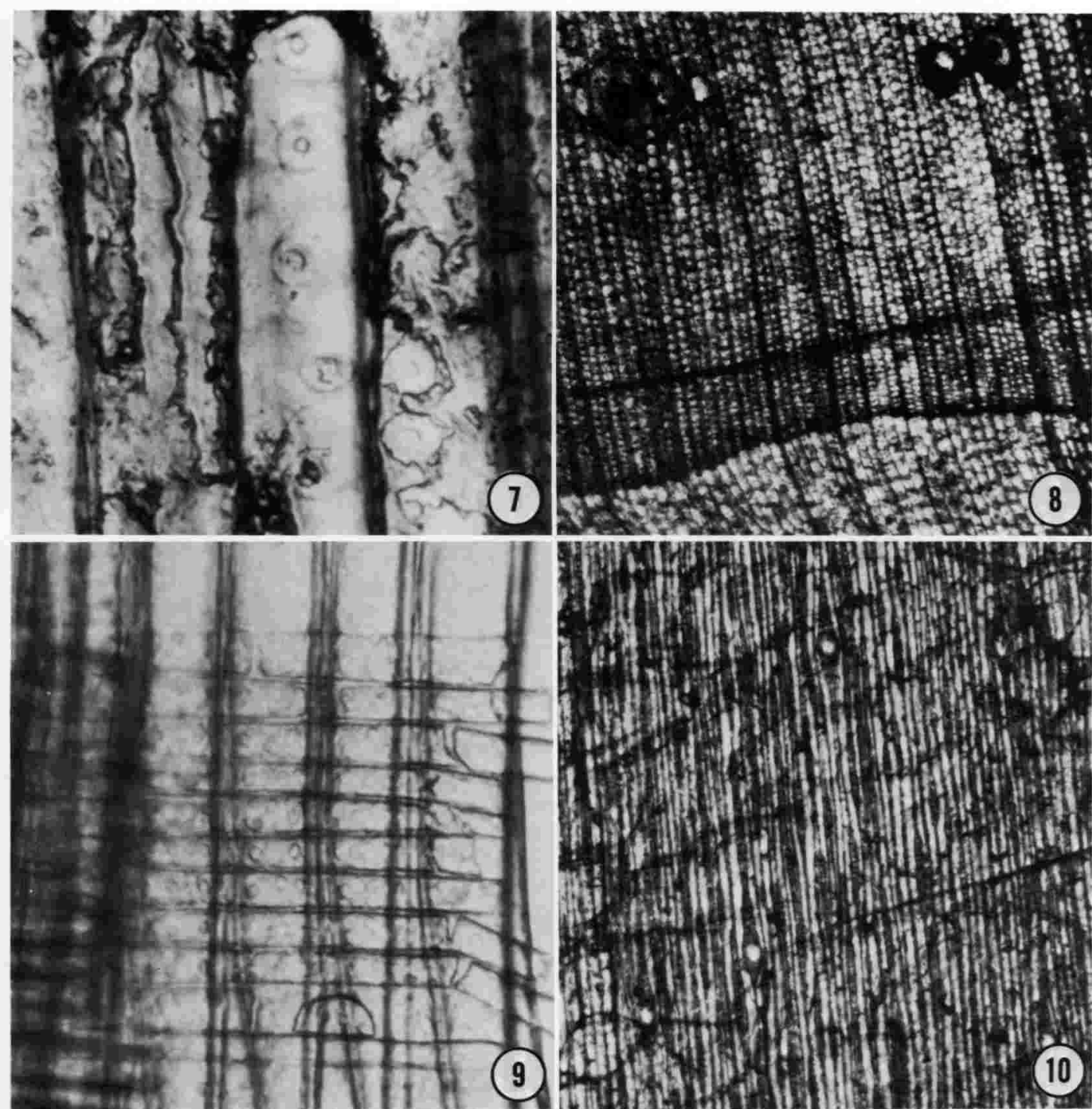

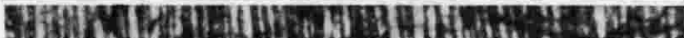

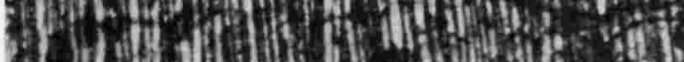
(2) 6.6.

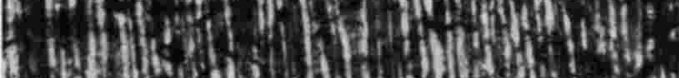
(1) Hed

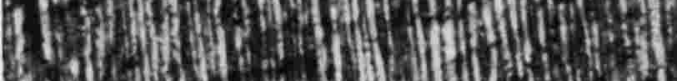

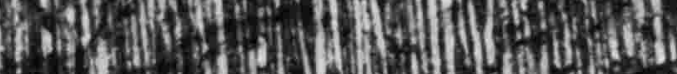

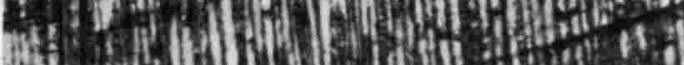
(t) 14.

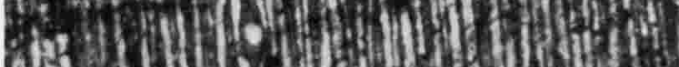
(1)

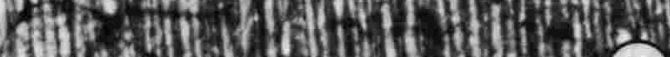
Af Wh

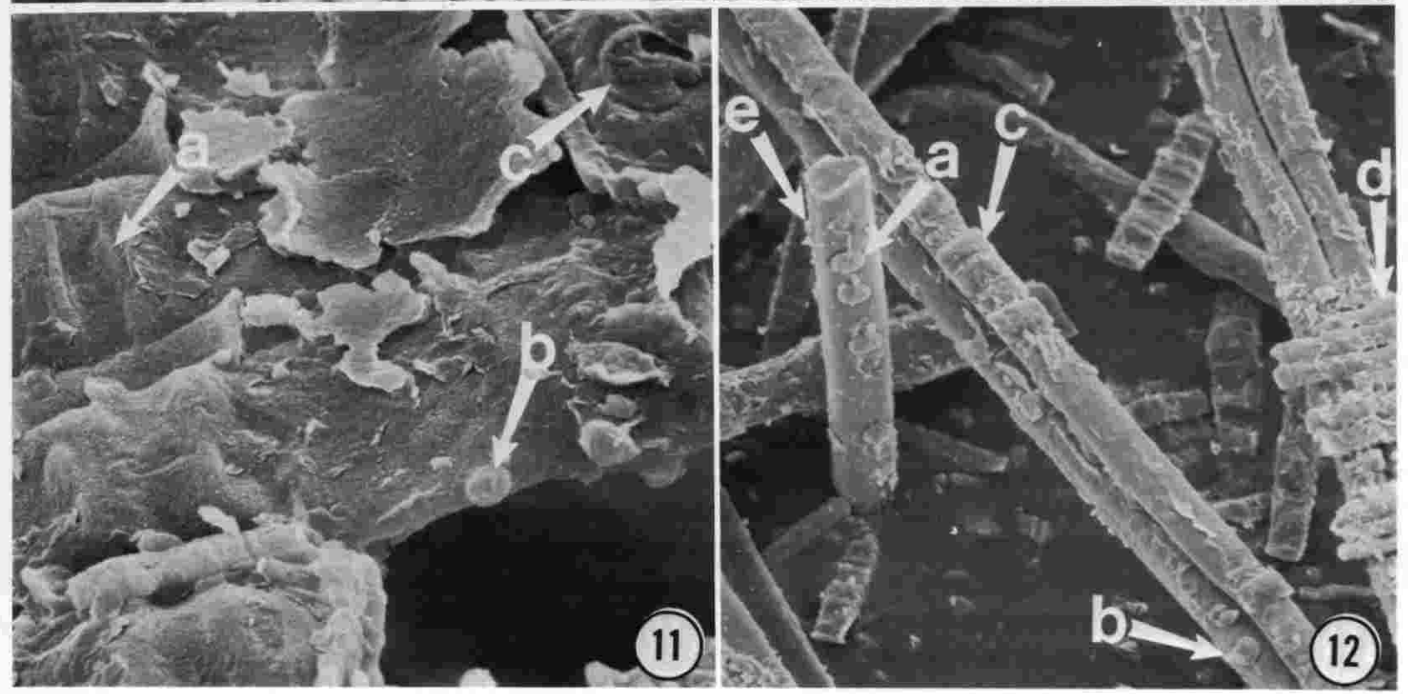


multiseriate alternate, numerous on early wood tracheids, apertures circular, frequently 6-10 $\mu \mathrm{m}$ in diam; crassulae frequent and distinct; transverse (ray) tracheids present, smooth, thinwalled with small, horizontal circular pits in early wood, bordered pits on tangential walls; ray parenchyma rectangular; small, 2-5 (usually 3 ) oval or circular pinoid pits with rare borders per crossfield.

Repository: Brigham Young Univ., 5028 (Holotype)

Locality: Four miles $(6.4 \mathrm{~km}) \mathrm{NW}$ of Durkee, OR (Sec. 20, T11S, R42E, Baker Quadrangle)

Horizon: Flow-on-flow basalts possibly Picture Gorge Basalt

Age: Middle to Upper Miocene

Etymology: This species is named for Brent J. Woolard of Baker, OR who made the original discovery.

Discussion-The family Pinaceae is represented by 10 genera in the extant flora. Among these genera, four groups have been distinguished based upon their ray morphology and whether normal horizontal and vertical resin ducts are present in their wood (Greguss, 1955; Watari, 1956; Roy and Hills, 1972).

Group one: Pinaceous woods having heterogenous rays with both horizontal and vertical resin ducts [Pinus, Picea, Larix, Cathaya (Hu and Wang, 1984), and Pseudotsuga].

Group two: Pinaceous woods with heterogenous rays without normal resin ducts [Cedrus and Tsuga].

Group three: Pinaceous woods with homogenous rays and only vertical resin ducts [Keteleeria].

Group four: Pinaceous woods having homogenous rays and lacking any resin ducts [Pseudolarix and Abies].

Because this fossil wood from Oregon has heterogenous rays with horizontal and vertical resin ducts, it is referable to group one.

The fossil pinaceous wood under consideration is characterized by the presence of numerous resin canals with thin-walled epithelial cells. This condition is constant in Pinus except in the nut and foxtail pines of the southwestern U.S. In these forms, thick-walled epithelial cells are interspersed among the usually thin-walled type (Bailey, 1909). Further, Bailey (1909) characterized pine as lacking wood parenchyma and Gothan (1905) noted an absence of spiral thickenings of the tracheid walls of the secondary wood. However, wood parenchyma may occur very rarely in some Pinus species such as $P$. monophylla Torr. \& Frem. and $P$. massoniana Lamb. (Greguss, 1955), whereas spiral thickenings were described in Pinus taeda by Penhallow (1907). Bailey (1909) also mentioned them in $P$. attenuata Lemm. and occasionally in other pines from the southwestern United States.

Fossil woods similar to Picea and Larix are assigned to Piceoxylon which is characterized among other things by having heavily lignified walls in the epithelial cells of its resin ducts. This character is not present in the fossil wood described in this paper. Therefore, this wood is placed with the pines.

Historically, the genus Pinus has been subdivided in various ways by different authors. Some (Shaw, 1914, 1924; Pilger, 1926; Duffield, 1952) have recognized a two-part division into the subgenera Haploxylon and Diploxylon. Others recognized three subgenera: Ducampopinus, Strobus and Pinus (Little and Critchfield, 1969; Van der Burgh, 1973) with Strobus and Pinus being essentially equivalent to Haploxylon and Diploxylon respectively (Kellogg et al., 1982). Greguss (1955) considered the wood of the subgenus Strobus or Haploxylon to be distinguished by the presence of smooth-walled ray tracheids, whereas, the $P i$ nus or Diploxylon subgenus is distinguished by ray tracheids with dentate or reticulate cell walls. Hudson (1960) utilized this characteristic in distinguishing Pinus species and classified the degree of ray tracheid dentation into 14 gradations ranging from smooth to completely reticulated.

Van der Burgh (1973) further subdivided these three subgenera into four sections and these sections into 15 subsections. Subgenus Strobus, he divided into the sections Strobus and Parrya and into the latter he placed the subsections Cembroides, Gerardianae and Balfourianae. The subsection Cembroides appears to be the most similar to the Oregon fossil pinaceous wood.

Fig. 7-12. 7. Closeup of radial section showing uniseriate pitting. $\times 600$. 8. Transverse section; notice the resin ducts and growth ring. $\times 40.9$. Radial section illustrating a ray; note the bordered pits in the crossfield and the blocky aspect of the ray parenchyma. $\times 400.10$. Tangential section with several rays containing horizontal resin canals. $\times 40$. 11. Scanning electron micrograph of a radial and partially tangential section, note the impression of the ray (a), the tangential pits (b) and the radial tracheary pit (c). $\times 1,900$. 12. Scanning electron micrograph of various elements of the xylem. Radial tracheary pitting (a \& b), ray cells (c \& d) and a tangential pit (e). $\times 200$. 
Comparing fossil species with related fossil material or sections of recent pine genera requires careful and detailed observations. The question of whether or not Tertiary pine species can be assigned to modern sections cannot be adequately answered. It is difficult to be certain all woods of the same type belong to only a single botanical species. Even among modern woods it is often difficult to make such a determination. Furthermore, it is not certain whether during the Cenozoic the species or sections had the same rate of change and differentiation. Thus, a comparison of fossil and recent woods serves only as a basis for analysis of the possible structure of evolutionary lineages within the genus rather than an attempt to demonstrate relationship to specific extant taxa. Because of this problem, we have placed our fossil wood in the fossil genus Pinuxylon Gothan rather than into Pinus. To date approximately 30 species of Pinuxylon have been reported from various localities in North America, Europe, and Asia (Krausel, 1949; Greguss, 1967; Van der Burgh, 1973, 1978). Of these species, only a few are similar to our fossil pinaceous wood. The most similar is $P i$ nuxylon parryoides. Pinuxylon parryoides, first described by Gothan (1911) as Pinus, was later placed in Pinuxylon by Krausel (1949). Van der Burgh (1973) emended $P$. parryoides by including Pinus baumani (reported by Read [1933] from the Eocene Yellowstone flora) and Pinus kelloggi (reported by Webber [1933] from the Pliocene Ricardo flora), among others. Thus, as emended, $P$. parryoides now spans almost the entire Tertiary. The Oregon specimen differs from $P$. parryoides in that it lacks the somewhat dentate ray tracheids of the latter (Hudson [1960] gradation 2).

Three species that have smooth ray tracheids similar to those of the Oregon material are Pinuxylon tarnocziense (Tucson) Greguss, $P$. haploxyloides Greguss and P. albicauloides Greguss. Pinuxylon tarnocziense differs from $P$. woolardii in having generally shorter rays; mostly two, sometimes three, pits per crossfield and ray tracheids in two to three layers per ray. Pinuxylon haploxyloides differs from this Oregon species substantially in that it has only a single, large pinoid pit in its crossfields and generally lower rays (1-12 cells). Pinuxylon albicauloides from the Miocene of Hungary and Canada differs from this Oregon material in having fenestrate crossfield pitting.

Torrey (1923) reported Pinuxylon cf. $P$. vateri (Platen) Rossler (1937) from Miocene volcanic ash deposits on Cape Blanco, OR. He considered his specimen to be similar to $P$. vateri described by Platen (1907) from Pliocene strata of California. Torrey (1923) noted that Platen's specimen differed from his in having dentate transverse (ray) tracheids. Both of these specimens, however, can be distinguished from $P$. woolardii on the basis of fewer horizontal resin ducts, lower rays, and only one or two large pits per crossfield.

The fossil wood is similar to certain living species of the subsections Paracembra (Shaw, 1914) or Cembroides (Van der Burgh, 1973), of the group Aristata (Greguss, 1955) or of the sections Parrya and Sula (Rol, 1932; Jacquiot, 1955; Boureau, 1956). These sections and subsections include five living species whose woods are similar to Pinuxylon woolardii. These include Pinus aristata Engelm. (bristle cone pine), $P$. cembroides Zucc. (Mexican nut pine), $P$. monophylla (single leaf Pinyon pine), $P$. edulis Engelm. (Colorado Pinyon pine), and P. balfouriana Jeffr. \& Murr. (foxtail pine).

Pinus aristata is similar to the Oregon specimen by virtue of its smooth walled ray tracheids and numerous rays, however, $P$. aristata has low rays (usually 7-9 cells high) with only a few horizontal resin ducts.

Pinus cembroides has high rays (20-25 cells) like $P$. woolardii, but differs from the latter species in having circular ray cells. Pinus edulis is similar to $P$. woolardii in that it has only a few ray tracheids, numerous rays, numerous horizontal resin ducts and elliptic crossfield pitting. They are distinguished from one another by the usually low rays (typically 810 cells) and larger resin ducts of $P$. edulis.

Pinus monophylla is similar to Pinuxylon woolardii in possessing numerous vertical resin ducts, either scattered or aligned in short rows, thin-walled longitudinal tracheids and relatively high rays ( $8-20$ cells). They can be differentiated from each other by thinner walled ray parenchyma and the two (rarely one or three) circular crossfield pits without any hint of borders in P. monophylla.

Pinus balfouriana and Pinuxylon woolardii both have very high rays, but they can be distinguished by the external walls of the ray tracheids of the former species being somewhat dentate.

Compression taxa presumed to be related to this group of extant species are poorly known from strata of Cenozoic age of western North America. Specimens similar to Pinus aristata were noted by Axelrod (1976) from the Paleogene Hillsboro and Hermosa floras (Oligocene) of New Mexico and the Creede flora (Oligocene-Miocene) of Colorado. Pinus balfouroides Axelrod, considered to be closely allied to $P$. 
balfouriana, has been reported from the Neogene Chalk Hills and Eastgate localities (Miocene) of Nevada (Axelrod, 1980, 1985).

It is interesting that the living species to which this fossil wood appears to be most closely related are presently living in rather dry environments and grow at relatively high elevations. This coincides to some degree with Hoxie's (1965) climatic evaluation of the Sparta flora. He compared the environment of the Sparta flora with that of the Blue Mountains flora, which Chaney (1959) considered to be a warm-temperate climate similar to the present climate of the southeastern United States. Hoxie (1965) concluded that the Sparta flora grew at a somewhat higher elevation and under slightly less favorable climatic conditions than the Blue Mountains flora.

Pinuxylon woolardii also supports research done on the paleoecology of of the nearby Succor Creek flora of Miocene age by Taggart and Cross (1980) and Cross and Taggart (1982). They summarized earlier climatic studies and demonstrated the existence of a series of changes in vegetational assemblages caused by probable volcanic activity, active tectonism and climatic modification. Significantly, one of their paleoassociations in the Succor Creek area is a pine-xeric assemblage where several pine pollen morphotypes are associated with palynomorphs of xeric plants, such as Ephedra (Gray, 1964; Taggart and Cross, 1980). Their evidence indicates a cool and equable climate throughout much of Succor Creek time with the development of more xeric conditions on south-facing slopes with the onset of a shift to summer-dry conditions. These conditions were probably similar to those under which Pinuxylon woolardii may have grown.

\section{LITERATURE CITED}

AXELROD, D. I. 1976. History of the coniferous forests, California and Nevada. Univ. Calif. Publ. Bot. II 70: $1-62$.

-1980. Contributions to the Neogene paleobotany of central California. Univ. Calif. Publ. Geol. Sci. 121: $1-212$.

-1985. Middle Miocene floras from Middlegate Basin, west-central Nevada. Univ. Calif. Publ. Geol. Sci. 129: 1-279.

BAILEY, I. W. 1909. The structure of the wood in the Pineae. Bot. Gaz. 48: 47-55.

Boureau, E. 1956. Anatomie vegetale. P.U.F., Paris 2: $333-524$.

Brooks, H. C., J. R. MCINTyre, ANd G. W. WAlker. 1976. Geology of the Oregon part of the Baker $1^{\circ}$ by $2^{\circ}$ Quadrangle. Oreg. Dept. Geol. Min. Ind. Geol. Map Ser. 7: 1-25.

ChANEY, R. W. 1959. Miocene floras of the Columbia Plateau, Part I. Composition and interpretation. Carnegie Inst. Wash. Publ. 617: 1-134.
, AND D. I. AXELROD. 1959. Miocene floras of the Columbia Plateau, Part II. Systematic considerations. Carnegie Inst. Wash. Publ. 617: 135-237.

Cross, A. T., AND R. E. TAggart. 1983. Causes of shortterm sequential changes in fossil plant assemblages: Some considerations based on a Miocene flora of the northwest United States. Ann. Mo. Bot. Gard. 69: $676-734$.

Duffield, J. W. 1952. Relationships and species hybridization in the genus Pinus. Ztschr. Forstgenet. Forstpflanz. (Silvae Genetica) 1: 93-100.

GothAN, W. 1905. Sur anatomic lebender und fossile Gymnospermenholzer. Preuss. Geol. Landesanst. Abh., New Ser. 44: 1-108.

-. 1911. Uber Braunkohlenholzer des rheinischen Tertiars. Jahrb. K. Preuss. Geol. Landesanst. 30: 516532.

GraY, J. 1964. Northwest American Tertiary palynology: The emerging picture. Ancient Pacific Floras: 2130 .

- AND L. R. KitTLEMAN. 1967. Geochronometry of the Columbia River Basalt and associated floras of eastern Washington and western Idaho. Amer. J. Sci. 265: 257-291.

GREGUSS, P. 1955. Identification of living gymnosperms on the basis of xylotomy. Akad. Kaido, Budapest.

. 1967. Fossil gymnosperm woods in Hungary. Akad. Kiado, Budapest.

Hoxie, L. R. 1965. The Sparta flora from Baker County Oregon. Northwest Sci. 39(1): 26-35.

Hu, Y. S., AND F. H. WANG. 1984. Anatomical studies of Cathaya (Pinaceae). Amer. J. Bot. 71(5): 727-735.

Hudson, R. H. 1960. The anatomy of the genus Pinus in relation to its classification. Inst. Wood Sci. 6: 2646.

JACQUIOT, C. 1955. Atlas d'anatomie des bois de Coniferes. Centre technique du bois, Paris, 2 133: 1-62.

KellogG, R. M., S. Rowe, R. C. KoepPen, AND R. B. Miller. 1982. Identification of the wood of the soft pines of western North America. IAWA Bull, New Ser. 3(2): 95-101.

KraUSEL, R. 1949. Die fossilen Koniferenholzer. Palaeontographica 89B: 83-203.

LitTle, E. L., JR., AND W. B. CRitchfield. 1969. Subdivision of the genus Pinus (pines). USDA For. Serv., Misc. Publ. no. 1144. Washington, D.C.

Penhallow, D. P. 1907. A manual of North American gymnosperms. Ginn \& Company, Boston.

Pilger, R. 1926. Pinaceae. In A. Engler and K. Prantl [eds.], Die Naturlichen Pflanzenfamilien. Ed. 2 13: 271-342.

PlateN, P. 1907. Untersuchungen fossiler Holzer aus dem Westen der Vereinigten Staaten von Nordamerika. Inaugural-dissertation. Leipzig.

READ, C. B. 1933. Fossil floras of Yellowstone National Park. I. Coniferous woods of Lamar River flora. Carnegie Inst. Wash. Publ. 416(1): 1-19.

RoL, R. 1932. Note sur un essaie de classification du genre Pinus d'apres des caracteres tires de l'anatomie du bois. Rapp. Congr. Soc., Sav. 65e: 333-341.

Rossler, W. 1937. Pliozane Koniferenholzer der Umgebung von Gleichenberg in Steiermark. Mitt. naturw. Ver Steiermark 74: 64-97.

RoY, S. K., AND L. V. Hills. 1972. Fossil woods from the Beaufort Formation (Tertiary), northwestern Banks Island, Canada. Canad. J. Bot. 50: 2637-2648.

Shaw, G. R. 1914. The genus Pinus. Arn. Arbor. Publ. 5: $1-96$. 
1924. Notes on the genus Pinus. J. Arn. Arbor. 5: 225-227.

TAggart, R. E., AND A. T. Cross. 1980. Vegetation change in the Miocene Succor Creek flora of Oregon and Idaho. In D. L. Dilcher and T. N. Taylor [eds.], Biostratigraphy of fossil plants-successional and paleoecological analyses, pp. 184-210. Dowden, Hutchinson \& Ross, Inc., Stroudsburg, PA.

TORREY, R. E. 1923. The comparative anatomy and phylogeny of the Coniferales. Part 3-Mesozoic and Tertiary coniferous woods. Mem. Boston Soc. Nat. Hist. 6(2): 41-106.

VAN DER BURGH, J. 1973. Holzer der niederrheinischen Braunkohlenformation, 2. Holzer der Braunkohlengruben "Maria Theresia" zu Herzogenrath, "Zukunft West" zu Eschweiler und "Victor" (Zulpich Mitte) zu
Zulpich. Nebst einer systematisch-anatomischen Bearbeitung der Gattung Pinus L. Rev. Palaeobot. Palynol. 15(2/3): 73-275.

1978. Holzer aus dem Pliozan der Niederrheinischen Bucht. Fortschr. Geol. Rheinld. u. Westf. 28: 213-275.

WATARI, S. 1956. Some abietinean woods from the Tertiary of Japan. J. Fac. Sci. Univ. Tokyo, Sect. III, Bot. 6(9): 419-437.

Waters, A. C. 1961. Stratigraphic and lithologic variations in the Columbia River Basalt. Amer. J. Sci. 259: 583-611.

WeBber, I. E. 1933. Woods from the Ricardo Pliocene of Last Chance Gulch, California. Carnegie Inst. Wash. Publ. 412(II): 113-134. 